\title{
El aspecto fiscal de la licencia de obras
}

\author{
por \\ FRANCISCO RIBÉS PUIG \\ Secretario de r. ${ }^{a}$ categoría y Diplomado en Administración local. \\ Oficial Mayor del Ayuntamiento de Cartagena.
}

SUMARIO: I. IDEAS GENERALES SOBRE LAS TASAS.-II. LAS TASAS EN LA JURISPRUDENCIA DEL TRIBUNAL SUPREMO Y DE LAS AUdiENCIAS TERRITORIALES.III. LA LICENCIA COMO HECHO IMPONIBLE: EL DEVENGO DE LA TASA EN LA LEGISLACION Y LA JURISPRUDENCIA.-TV. EXCEPCIONES A LA REGLA GENERAL: 1. Licencia sin tasa en las obras fuera de poblado. 2. Licencia sin tasa en los casos de exención. 3. La orden de obras.-V. OTROS SUPUESTOS SOBRE EL DEVENGO DE TASAS EN RELACION CON LAS LICENCIAS: 1. La licencia otorgada por silencio administrativo. 2. La transmisión de la licencia. 3. La nueva licencia por caducidad.-VI. EL ORGANO COMPETENTE PARA EL ACTO DE LIQUIDACION.-VII. LA INICIATIVA DOMINICAL O PETICION DE PARTE COMO REQUISITO JURIDICO O PRESUPUESTO DE LA LICENCIA.-VIII. LA LEGALIZACION DE OBRAS DEL ARTÍCULO 171 DE LA LEY DEL SUELO.-IX. EL CAMBIO DE PRETENSION.-X. EL SUJETO PASIVO DE LA TASA.-XI. LA FORMULA DE «PREVIO PAGO».-XII. TRATAMIENTO FISCAL DE LA INFRACCIÓN URBANÍSTICA: LA INSPECCIÓN DE RENTAS Y EXACCIONES Y LAS OBRAS SIN LICENCIA.

\section{IDEAS GENERALES SOBRE LAS TASAS}

El artículo primero de la Ley de Tasas y Exacciones parafiscales de 26 de diciembre de 1958 configuró una definición de las tasas que había de pasar a la Ley General Tributaria de 28 de diciembre de 1963: «Aquellos tributos cuyo hecho imponible consiste en la utilización del dominio público, la prestación de un servicio público o la realización por la Administración de una actividad que se refiera, afecte o beneficie de modo particular al sujeto pasivo», mientras que los impuestos son «los tributos exigidos sin contraprestación, cuyo hecho imponible está 
constituido por negocios, actos o hechos de naturaleza jurídica o económica que ponen de manifiesto la capacidad contributiva del sujeto pasivo, como consecuencia de la posesión de un patrimonio, la circulación de los bienes o la adquisición o gasto de la renta».

Buena parte de las dificultades que saltan a la vista al examinar, siquiera sea superficialmente, la tasa por licencia de obras, radican en aquella conceptual distinción entre la tasa y el impuesto y en la aplicación a aquélla de normas y criterios propios de éste. La posibilidad de inadecuación está reconocida expresamente en el preámbulo de la Ley General Tributaria cuando dice: «Salvo escasas excepciones, las normas contenidas en la Ley son formuladas como aplicables a las tasas, a las contribuciones especiales y a los impuestos. De este modo se pretende por la Ley General que de no existir esencial inadecuación entre la norma y el supuesto de hecho sean aplicables todos sus preceptos a las tres clases de tributos que la misma establece».

Por otra parte, aquella definición legal no hace sino recoger caracteres distintos aceptados por la doctrina de los autores y por la jurisprudencia.

García-Trevijano (1) subraya la diferencia clásica advertida por De VitTi di MarCo, H. Dalton y MoRseldi, de que mientras el impuesto se refiere a la financiación de los servicios públicos generales uti universi y la tasa a los servicios públicos uti singuli, especiales o divisibles, la tasa tiene un sentido típico de contraprestación, se paga voluntariamente por la utilización del servicio y está en relación con el coste de producción del mismo. Ahora bien, esta concepción clásica de la tasa como contraprestación y como fenómeno de cambio en virtud de la divisibilidad de los servicios ha sido-dice-superada: el principio de voluntariedad de pago de la tasa se ve comprometido por la existencia de tasas obligatorias. ¿Cuál es la diferencia entre la tasa obligatoria y el impuesto? La diferencia está en que el servicio ha de prestarse inexcusablemente y ha de acreditarse su prestación en el caso de la tasa, no ocurriendo así en el impuesto.

(1) «Tasas obligatorias», Revista de Administración Públicia, núm. 15, påginas 161 y 55 . 
García de Enterría (2), que ve en Adam Simth el origen, la raíz liberal de la construcción clásica de la tasa, cree que el correctivo de la teoría de la misma debe ser de concepto. Los servicios públicos genuinamente tales no están organizados para atender una suma más o menos extensa de utilidades individuales, sino en vista de finalidades sustancialmente colectivas. Sin necesidad de amplio desenvolvimiento de esta idea nos bastará remitir a la simple experiencia diaria para comprender hasta qué punto los servicios públicos vertebran y condicionan, como verdaderas estructuras, la sociedad de nuestro tiempo. Ante ese hecho capital pierde toda significación la razón ordinariamente aducida en pro del tratamiento cuasi comercial de la tasa, la de la voluntariedad de su uso. Aparte de que hay tasas por servicios forzosos (la admisión teórica de estas llamadas tasas obligatorias o con la obligación que en tan grave aprieto colocan a la concepción clásica de la tasa, es conocida), bien puede decirse que en todos los demás casos la libertad de usar o no el servicio es ilusoria, pues significa la libertad de renunciar a una parte fundamental de la vida social. $Y$ agrega que el verdadero título de la tasa en cuanto auténtica exacción pública, es la ley. La ley determina el nacimiento de la obligación de la tasa, su extensión y todas sus posibles determinaciones jurídicas. El particular alcanza con su voluntad a provocar o no el hecho al cual la ley ha ligado la obligación de pagar tasa, eso es todo, pero es precisamente en la ley donde la tasa tiene su único título.

CARCeller Fernández (3) considera que en Derecho español el procedimiento para el otorgamiento de la licencia de edificación se inicia siempre a petición de parte. $Y$ nuestro compañero ALBI (4) remueve toda apariencia contractual en el acto de autorización. Si en realidad hay contrato-dice-podemos afirmar que no existe autorización. Mas a la falta de vinculación de voluntades no debe atribuirse tal alcance que elimine la voluntad del interesado de la realización de la actividad de que se trata. Esta

(2) «Sobre la naturaleza de la tasa y las tarifas de los servicios públicos», R. A. P., núm. 12, págs. 138 y 139.

(3) El derecho y la obligación de edificar, Editorial Montecorvo, pág. 239.

(4) Tratado de los modos de gestión de las Corporaciones locales, Editorial Aguilar, Madrid, 1960, pág. 684. 
voluntad es esencial y sin la misma la autorización no existiría, ya que se produce a consecuencia de una voluntaria petición del interesado y se desarrolla mientras voluntariamente quiere éste llevarla a la práctica. La voluntad del autorizado no puede faltar nunca y precisa considerarla no como un elemento esencial del acto, sino como un requisito jurídico del mismo, como un «presupuesto» indispensable para la eficacia de la autorización.

\section{LAS TASAS EN LA JURISPRUDENCIA DEL TRIBUNAL SUPREMO Y DE LAS AUDIENCIAS TERRITORIALES}

La Ley de Régimen local incluye entre las exacciones municipales que enumera su artículo 434, y encabezando la lista, los derechos y tasas «por aprovechamientos especiales o por la prestación de servicios».

Se trata, según el 435, de la prestación de servicios públicos municipales que beneficien especialmente a personas determinadas o por ellas se provoquen también especialmente. También de los aprovechamientos especiales de que sean susceptibles las propiedades e instalaciones municipales destinadas al uso público o de común aprovechamiento, en los casos que señala el número 2 del mismo.

$\mathrm{Y}$ el artículo 10 del Reglamento de Haciendas locales prevé la existencia de tasas obligatorias al decir que «cuando no se produjera a petición de los interesados la utilización de los servicios, únicamente podrán imponerse derechos y tasas por los que sean de la competencia municipal».

La jurisprudencia del Tribunal Supremo ha venido insistiendo en las notas o características expresadas en el apartado anterior. Debe «entenderse por tasa, que es sinónimo de derecho en la calificación de esta clase de ingresos municipales-dice la sentencia de 17 de octubre de 1945 (Aranzadi 1.078) (5)-, la parte de coste de producción de un servicio público que puede frac-

(5) Todos los números que siguen a las sentencias del Tribunal Supremo corresponden a los marginales del Repertorio Aranzadi y los que acompañan a sentencias de las Audiencias Territoriales se refieren a los de la Recopilación de Santillana. 
cionarse según el consumo o aprovechamiento individual y efectivo, y por tanto, puede cobrarse a los particulares en proporción a la utilidad que de este servicio obtienen»(6).

\section{LA LICENCIA COMO HECHO IMPONIBLE: EL DEVEN- GO DE LA TASA EN LA LEGISLACION Y LA JURISPRUDENCIA}

Con antecedente en el 137 y 138 de la Ley de Régimen local y el 21 de su Reglamento de Servicios, el artículo 165 de la Ley

(6) Sentencia de 16 de enero de 1959 (514): «... la tasa responde a un determinado servicio y obedece al principio de la contraprestación específica en cuanto responde a la utilización que el particular realice, y el arbitrio obedece al principio de la contraprestación general, abonando el impuesto la masa contribuyente afectada».

Sentencia de 21 de marzo de 1965 (3.453): «Es premisa indeclinable para toda exigencia y percepción de tasas, lo mismo trátese de tasas de la Administración general del Estado que en la de las Corporaciones locales, el de que las tasas, a diferencia o en contraposición de los impuestos y arbitrios, no pueden ser vistas como algo imperativamente exigible y sin más sin otra razón que la de la necesidad de la entidad soberana o infrasoberana que debe percibirlas, sino como la verdadera prestación de un servicio y no de uno meramente invocado, sino de uno efectivamente rendido, de tal suerte que en donde-por los motivos que fuesen-no haya habido prestaci6n del servicio, no puede haber cobro de tasa».

Sentencia de 21 de junio de 1967 (3.014): «... las tasas municipales representan, pura y simplemente, una retribución de los servicios directamente prestados por la Corporación o sus organismos, una compensación de los: aprovechamientos especiales de las propiedades o instalaciones municipales que comporten restricciones del uso público o especial depreciación de los bienes o instalaciones, o aun sin esto impliquen un beneficio particular».

Por su parte, las Salas de lo Contencioso-administrativo de las Audiencias: Territoriales acotan igualmente estos caracteres. La sentencia de la Audiencia Territorial de Granada de 27 de febrero de 1963 (Santillana 1.410) diceque «las tasas, tal como vienen establecidas y reguladas por los artículos 435 , 436 y 446 de la Ley de Régimen local son sólo un medio por ésta concebido para que las Corporaciones locales repartan proporcionalmente el coste de determinados servicios públicos, $\mathbf{u}$ obtengan los rendimientos de que. sean susceptibles las propiedades o instalaciones municipales de uso público. o de común aprovechamiento cuando de ellos se beneficien personas o empresas determinadas».

En el mismo sentido la de la Audiencia Territorial de Las Palmas de 18 de junio de 1963 (1.421) dice: «... la propia esencia de prestación dineraria debida como contraprestación por el desarrollo de una actividad que afecta de un modo particular al deudor postula inexcusablemente que en. tanto no se produzca el hecho imponible representado por la prestación del servicio, la utilización del dominio público o el ejercicio de la actividad, no nace la relación jurídica tributaria, ni por tanto, la deuda y su atribución a un sujeto». 
del Suelo establece la sujeción o sometimiento a previa licencia municipal para las obras que expresa y mediante el procedimiento, que también indica, preestablecido por el indicado Reglamento en su artículo 9.

$\mathrm{Y}$ el artículo 440 de la Ley de Régimen local ordena que se entiendan comprendidos entre los derechos y tasas por prestación de servicios una larga enumeración de conceptos entre los que figura el 7., que es como sigue: «Licencias para construcciones y obras en terrenos sitos en poblado o contiguos a vías municipales fuera de poblado».

El 436 dispone que «la obligación de contribuir por derechos y tasas se funda en la utilización del servicio o en el aprovechamiento por el interesado. En consecuencia, la mera existencia del servicio o la posibilidad de aprovechamiento no facultarán, en ningún modo, a los Ayuntamientos para la exacción de estos gravámenes». $\mathrm{Y}$ el 437 establece para todos los derechos y tasas, hecha excepción de la de sello municipal, que se devengará «desde la fecha en que se autorice la prestación del servicio, o se conceda el aprovechamiento particular».

En consecuencia, hay que concluir que la tasa por licencia de obras se devenga por el otorgamiento de la licencia, y que la utilización del servicio se produce cuando la licencia se ha otorgado. La Administración establece una norma general y determina con posterioridad las situaciones individuales que se hallan de acuerdo con dicha norma urbanística, mediante la técnica de la licencia. Como dice González Pérez (7), presupone ésta una prohibición condicionada, la prohibición de que se ejercite una actividad en tanto no se verifique el cumplimiento de determinados requisitos o condiciones. La licencia es, pues, el acto administrativo por el que se remueve la prohibición.

Volviendo a la idea inicial, si la situación individual o concreta se acomoda a la norma preexistente, la licencia-acto reglado que se habrá de producir en contemplación de los fines del artículo 21 y por el procedimiento del 9.9, ambos del Reglamento

(7) «Las licencias urbanísticas», REVISTA DE ESTUdIOS DE LA VIDA LOCAL, número 154, pág. 499. 
de Servicios-se otorga. Si no es así, se deniega en forma motivada.

Desarrollándose en uno y otro caso la misma actividad administrativa debe entenderse a estos efectos fiscales que la tasa por licencia se devenga solamente si la licencia se concede y que en esta concesión u otorgamiento consiste el hecho imponible y la prestación del servicio cuya contraprestación es la tasa. Como apunta certeramente la sentencia de 18 de junio de 1963 de la Audiencia Territorial de Las Palmas (8), en tanto no se produzca el hecho imponible no habrá nacido la relación jurídico-tributaria. Ni se dará, pues, si la licencia no se otorga, ni nacerá antes de que sea concedida.

También es unánime y reiterada la jurisprudencia del Tribunal Supremo en este punto. Por ejemplo, la sentencia de 3 de febrero de 1967 (351) dice: «sabido es que sin servicio utilizable, por indudablemente instalado y por positivamente utilizado-sea espontáneamente o a fortiori—no hay tasa fundadamente exigible». Y la de 1 de marzo del mismo año 1967 (810) subraya que «es manifiesto que si el servicio no se ha prestado, la obligación fiscal no ha nacido».

Por otra parte, el hecho imponible-otorgamiento de la licencia-es indispensable y aun ajeno al de ejecución de la obra. La licencia se otorga, por supuesto, para que la obra se realice. Pero no hace más que conceder facultad para llevarla a efecto; en. modo alguno impone su ejecución. Como veremos, difícilmente puede admitirse como verdadera obligación la de edificar.

Una sentencia de 13 de marzo de 1965 (1.647) dice: «que según se infiere del artículo 165 de la Ley del Suelo y constituye. o corresponde a la naturaleza de las licencias de edificación, su otorgamiento no constituye al particular en la ineludible obligación de edificar, sino que le faculta para realizar la construcción. autorizada o renunciar a la utilización de la licencia».

Solicitada fuera de plazo la rehabilitación de una licencia de. obras caducada, - el Tribunal Supremo declara sin embargo no haber lugar a la devolución de la tasa percibida (9).

(8) Vide nota 6, in fine.

(9) La sentencia de 2 de octubre de 1956 (3.236) dice: «Que si bien el ar- 
Es decir, que «utilizar el servicio» y «ejecutar la obra» son cosas enteramente diferentes. La efectividad de la tasa es independiente de que la obra se lleve a cabo.

\section{EXCEPCIONES A LA REGLA GENERAL}

Sólo en el caso de que la licencia se otorgue, habrá lugar a devengo de la tasa, como hemos visto. Pero no siempre que aquel otorgamiento se produzca.

Con arreglo al artículo 9.. del Fuero de los Españoles y 27 de la Ley de Régimen jurídico de la Administración del Estado, la tasa requiere un norma legal de creación y, a tenor de lo mandado por los artículos 718 y 719 de la Ley de Régimen local, una Ordenanza que la desarrolle, motivo por el cual, como dice la sentencia de 10 de noviembre de 1963 (4.677), «preciso es admitir que no todo supuesto de intervención administrativa en la esfera de la actividad del particular a través de la técnica de la licencia $\mathrm{u}$ otro modo de actuar administrativo, queda sujeto a una tasa, sino únicamente los supuestos de exacción que la Ley establece y una Ordenanza con sujeción a la Ley aplique y ordene...».

\section{LICENCIA SIN TASA EN LAS OBRAS FUERA DE POBLADO.}

Ahora bien, la Ley de Régimen local, en el número 7.o de su artículo 440, ya hemos visto que incluye entre las tasas por prestación de servicios las «licencias para construcciones y obras en terrenos sitos en poblado o contiguos a vías municipales fuera de poblado».

De lo que dedúcese, como conclusión, la inexigibilidad de la tasa por licencias concedidas para obras fuera de poblado y no contiguas a vías municipales. La sentencia del Tribunal Supremo de 5 de octubre de 1967 (3.402) hace suyo el siguiente consideran-

tículo 436 de la vigente Ley de Régimen local establece que la obligación de contribuir por derechos y tasas se funda en la utilizacion del servicio, debe entenderse, en la situación litigiosa, que el Ayuntamiento le prestó efectiva y realmente al conceder la licencia, tras el estudio por sus técnicos de los planos y demás documentos presentados, sin haber lugar, por tanto, ahora, a la devolución de las cantidades satisfechas en su dia por aquel concepto». 
do de la apelada: «que si relacionamos el artículo 8. del Reglamento de Servicios de las Corporaciones locales con los artículos 61 y siguientes, 165 y 166 de la Ley del Suelo y 435 y 440 , número 7, de la Ley de Régimen local, hemos de llegar a la conclusión de que no siempre que sea necesaria la licencia municipal para efectuar obras o construcciones, tiene el Municipio facultad para cobrar derechos y tasas por la expedición de esas licencias, sino solamente cuando las construcciones $u$ obras tengan lugar en terrenos sitos en poblado o contiguos a vías municipales fuera del poblado» (10).

Decisivo es el concepto de «poblado», según la redacción del repetido número 7 del artículo 440, para la viabilidad de la tasa. La extensa y conocida sentencia del Tribunal Supremo de 30 de octubre de 1956 (3.566) aborda la cuestión comenzando por el concepto gramatical o filológico y trata después de concordar o sistematizar aquel precepto con otros del Reglamento de Obras, Bienes y Servicios de 14 de julio de 1924 tales como el 57, que alude, aún más restringidamente, al «suelo o subsuelo del casco del término municipal», y el 58 , relativo a alineaciones y rasantes de «toda construcción que se levante en el término municipal respectivo», como también el 64, señalando atribuciones municipales en materia de viviendas y apertura de establecimientos industriales, aclarado por Real Orden de 30 de diciembre de 1924 en el sentido de que era aplicable a todas las obras que se realicen en el término municipal.

Los hechos de esta sentencia son anteriores a la Ley del Suelo y, con mucha más anticipación, a los preceptos hoy vigentes en materia de actividades industriales. Gira, por otra parte, en torno de la exigibilidad de la licencia, y no hace, referencia al problema de la tasa.

La de 5 de octubre de 1967, antes citada, dejando a salvo la facultad de otorgar la licencia y el deber de solicitarla, se limita

(10) A su vez, la de 31 de octubre de 1961 (3.262) puntualiza que lo que ha de ser contiguo es el terreno donde se edifica, sin que pueda interpretarse el precepto legal en el sentido de referirlo exclusivamente a las vías contiguas a lo edificado, pues de este modo quedaría siempre al arbitrio de los interesados el abono de la tasa, quienes con retirar unos cuantos metros la edificación imposibilitarían su percepción. 
a declarar la improcedencia de que se exija tasa por licencia de obras fuera de poblado y no contiguas a vías municipales.

Se da, por tanto, una inadecuación entre las disposiciones reguladoras del deber de licencia y la norma legal que autoriza la percepción de una tasa por su otorgamiento. Es posible que ello obedezca a la superposición o coexistencia de textos legales que responden a ideas diferentes y aun a épocas también distintas. La redacción del número 7 del artículo 440 de la Ley de Régimen local aún vigente, está tomada y literalmente copiada del apartado $g$ ) del artículo 360 del Estatuto municipal. El Reglamento de Servicios y la Ley del Suelo han traído una regulación de la técnica de la licencia antes prácticamente inédita. Mientras las ideas y la legislación de policía han experimentado una conmoción revolucionaria, la legalidad fiscal da amparo a una tasa propia de los tiempos de la legislación de ensanche que aflora aún en preceptos de la Ley de Régimen local como el 129 y siguientes de la misma. Mas la Ley del Suelo ya no es una ley de ensanche y según ella, haya o no haya plan, sea cual sea la situación de hecho, se proyecta sobre todo el término municipal la policía urbanística y se imponen, aun sobre el suelo rústico, limitaciones tan importantes como las de su artículo 69.

A falta de una adecuada regulación de la licencia de obras es posible que el apartado $g$ ) del Estatuto municipal aspirase a incluir implícita en la norma fiscal una limitación de policía, de manera que fuera de poblado y sin contigüidad a vía municipal no fuera exigible licencia. En este último criterio legal late el criterio poco urbanístico de la demanialidad. Si no se sometían a licencia más obras que las de aquella localización territorial, es claro que el devengo de tasas por licencia no podía extenderse a otras.

Pero si la hipótesis no se considera válida, su desestimación nos conduce a peor conclusión. La idea de que subsiste el deber de solicitar licencia y cesa el derecho de devengar la tasa, trae consigo la imposición sobre las enflaquecidas Haciendas locales de un deber de prestar servicios gratuitos para el que no encontramos ninguna justificación. $Y$ en efecto, resulta curioso observar en la larga enumeración de los derechos y tasas por presta- 
ción de servicios, tanto en el artículo 368 del Estatuto municipal como en el 440 de la Ley de Régimen local, que sólo existe una limitación territorial al devengo de la tasa por licencia de obras.

$\mathrm{Y}$ en el caso, frecuentísimo, de la construcción de establecimientos industriales en lugares alejados, se habrá de producir el ilógico resultado de que aquella localización impide el devengo de la tasa por licencia de obras pero se podrá percibir la de apertura, sin que se nos alcance justificación para esta dualidad de trato. Como no la hay, en general, para la prestación gratuita de otros servicios que los que señala el artículo 441 de la Ley de Régimen local. Ni para otras bonificaciones y exacciones que las de los artículos 438 y 439, sin que olvidemos por ello que una cosa es la exención y otra la no sujeción. Precisamente la no sujeción a tasa de las licencias de obras fuera de poblado y no contiguas a vías municipales a quien más beneficia no es precisamente a las clases modestas.

El Tribunal Supremo, en su reciente sentencia de 24 de junio de 1968 (3.499) acepta que «en la actualidad y en los supuestos de obras fuera de poblado y no contiguas a vías municipales, aunque se precise licencia por exigencia de una norma administrativa (art. 165 de la Ley del Suelo), sin embargo, falta la suficiente habilitación para la exigencia de la tasa, por ausencia de una norma fiscal que así lo disponga; sin que, por otra parte, la desarmonía pueda explicarse sólo por razón de las fechas en que se promulgan una y otra norma, puesto que no han faltado ocasiones en las posteriores reformas de las Haciendas locales pára haber podido corregir semejante discordancia y, no obstante, se ha mantenido el régimen anterior: el de la Ley de 24 de junio de 1955».

Se recuerda en la misma sentencia la doctrina reiterada de que cuando hay una ley aplicable al caso no es lícito acudir a la analogía, y la distinción entre ésta y la interpretación extensiva, en apoyo de la imposibilidad de aplicar la norma analógica del número 26 del artículo 440 de la Ley de Régimen local, y se declara que el Ayuntamiento vulneró la legalidad al extender mediante Ordenanza fiscal a todo el término municipal la facul- 
tad que el número 7.o del artículo 440 de la Ley de Régimen local sólo autoriza para obras en poblado o contiguas a vías municipales fuera de poblado.

Creemos entonces, como antes hemos apuntado, que esta cuestión reclama la atención del legislador y esperamos que en próximas ocasiones de reforma hacendística será recogida una situación que urge resolver por las razones expuestas.

\section{LICENCIA SIN TASA EN LOS CASOS DE EXENCIÓN.}

Los de exención serán, desde luego, otros supuestos de licencia otorgada que no origina devengo alguno. Pero quedando restringidas aquellas exenciones a los tres sujetos públicos que señala el artículo 439 de la Ley de Régimen local. Por lo que al Estado se refiere, obvias razones que tienen implícita acogida en el artículo 167 de la Ley del Suelo convierten en no sujeción, lo que pudo parecer hipótesis de exención.

La sentencia de 23 de febrero de 1968 (1.202) puntualiza que cuando se trata de construcciones proyectadas por órganos de la Administración central, el cumplimiento de lo dispuesto en el artículo 167 de la Ley del Suelo no supone someterlas a licencia municipal. Es decir, que la notificación de conformidad de los proyectos con los plazos de ordenación ni equivale a la previa licencia ni constituye una especial modalidad de ésta, en tanto que la de disconformidad del proyecto estatal con el planeamiento urbanístico tampoco significa la denegación de la licencia municipal, pues lo cierto es que están exceptuadas del requisito de la licencia municipal «las obras realizadas por los Departamentos ministeriales, organismos autónomos y servicios estatales que actúan con arreglo a sus propias normas de competencia».

\section{LA ORDEN DE OBRAS.}

Tampoco habrá devengo de tasa, por inexistencia de licencia que a ello dé lugar, en la orden de obras dada por la Administración con fundamento en lo dispuesto por los artículos 168 y 169 de la Ley del Suelo.

Creemos que es así porque en nuestro Derecho la licencia se 
produce siempre a iniciativa-libre o condicionada-del particular. La orden de ejecución de unas obras, dada por la autoridad, no constituye acto de licencia, no remueve límites, no levanta prohibiciones, sino que impone conductas y obliga al cumplimiento de deberes de conservación. Parece haberlo advertido el legislador de la Ley del Suelo cuando en el número 1 de su artículo 171 se refiere a «... los actos relacionados en el artículo 165 que se efectuaren sin licencia $u$ orden de ejecución...», con lo que es obvio que la conjunción disyuntiva separa dos cosas distintas. Pero aparte esto que pudiera parecer sutileza gramatical, a igual conclusión se llega mediante una interpretación lógica y sistemática de nuestro Derecho positivo. Volveremos sobre este punto.

\section{OTROS SUPUESTOS SOBRE EL DEVENGO DE TASAS EN RELACION CON LAS LICENCIAS}

En un tercer grupo de supuestos incluiremos aquellos de la licencia otorgada por silencio administrativo y los de transmisión y caducidad.

\section{LA LICENCIA OTORGADA POR SILENCIO ADMINISTRATIVO.}

¿Dará lugar a exaccionar la tasa el supuesto de licencia de obras otorgada por silencio administrativo?

GarRIDo Falla (11) señala cómo en sus comienzos la doctrina del silencio administrativo sirvió tan sólo de medio para que el particular plantease ante la jurisdicción contencioso-administrativa la cuestión que la Administración no había querido resolverle favorablemente, lo que postulaba una interpretación negativa o desestimatoria del silencio. Hoy, en cambio, se ha querido utilizar también el silencio administrativo como un arma para combatir la pasividad o negligencia administrativa, suponiéndole entonces una interpretación positiva que, no obstante, sigue siendo excepcional. Señala que aquella excepción se admite en

(11) Tratado de Derecho administrativo, vol. I, 3.* edición, Instituto de Estudios Políticos, Madrid, 1964, pág. 502. 
el artículo 95 de la Ley de Procedimiento administrativo, y entendiendo derogado por su disposición final $10^{a}$ el artículo $28 \mathrm{del}$ Reglamento de Procedimiento del Ministerio de Trabajo, se atribuye valor positivo al silencio administrativo en el artículo 9.o del Reglamento de Servicios de las Corporaciones locales.

Esta significación positiva del silencio de la Administración conduce a la autorización tácita y presupone la existencia del derecho o facultad cuyo ejercicio se autoriza. Si la institución se justifica como arma para combatir la pasividad de la Administración y en la entraña de aquella autorización tácita está precisamente aquella pasividad, ¿cómo ha de ser posible el devengo de la tasa por una licencia otorgada precisamente por silencio?

Cabe dudar incluso de aquel otorgamiento, ya que en el sentido formal no se ha producido. La licencia es un acto reglado que se dicta a través de un procedimiento señalado en el artícu1o 9. del Reglamento de Servicios, previa la actividad de constatación a que se refiere el artículo 21 del mismo texto. La obligación de contribuir por la tasa a que la licencia da lugar se funda en la utilización del servicio, pero por pasividad de la Administración no ha funcionado servicio alguno; no se ha desarrollado en favor del particular ni en interés público la actividad que prescriben las disposiciones legales antes anotadas. Ciertamente, el resultado podrá estimarse que ha sido el mismo: la licencia, pero parece inadmisible fundar la exacción en tan utilitario como fútil argumento.

La Administración municipal ha infringido la exigencia legal contenida en el artículo 373 de la Ley de Régimen local y se ha cruzado de brazos ante la petición de un particular omitiendo toda actuación propia de función que como la de policía urbanística es irrenunciable. A consecuencia de este no hacer se ha producido la licencia; en la terminología del apartado a) del párrafo séptimo del artículo 9. del Reglamento de Servicios, «ha quedado otorgada la licencia por silencio administrativo», expresión distinta de la que más gráficamente se usa en el párrafo $b$ ) que subsigue y que habla de «entenderse» denegada la licencia por silencio administrativo.

En favor de la percepción de la tasa podrá argüirse el enri- 
quecimiento del particular que obtiene los efectos habilitantes de la licencia sin contraprestación alguna por su parte. Pero también cabría hablar del enriquecimiento injusto de la Administración al percibir la tasa por un servicio que no ha prestado. Creemos por este motivo que no procede.

\section{La tRANSMisióN DE LA LICENCIA.}

Parece claro que la transmisión de la licencia no implica sư nuevo otorgamiento. CARCELLER FERNÁNDEZ (12) al referirse a la doctrina italiana alude a LUCIFREDI para quien en la licencia de obras, aunque sea en forma extremadamente atenuada, persiste un carácter personal que no puede ser olvidado, dado que la autorización se concede no sólo para que se construya determinado edificio, sino para que lo sea por parte del peticionario, puesto que si éste vende el terreno el comprador debe dirigirse nuevamente a la Administración municipal, la que puede negar el traspaso. Mas esta opinión de LUCIFREDI, discrepante de otros autores italianos, no parece que pudiera prevalecer en nuestro Derecho a la vista de lo dispuesto en el artículo 12 del Reglamento de Servicios.

GoNZÁlez PÉREZ (13) al hablar de la transmisibilidad de la licencia dice que «las licencias a que se refiere el artículo 165 de la Ley del Suelo, no se refieren a las cualidades de un sujeto o al ejercicio de actividades sobre el dominio público, sino a las condiciones de una obra; se otorgan en función de la concurrencia de determinadas circunstancias objetivas, abstracción hecha de la persona que vaya a realizar la actividad».

A la vista del artículo 13 del Reglamento de Servicios es claro que la transmisión de la licencia exige tan sólo que los sujetos de la misma lleven a efecto una dación de cuenta a la Administración cuya omisión hace a uno y otro responsables. No hay, pues, licencia nueva, ni se dará lugar, por tanto, a devengo de tasa por su otorgamiento.

(12) Ob. cit., pág. 167.

(13) Op. cit., $R E V L$, núm. 154, pág. 540. 


\section{LA NUEVA LICENCIA POR CADUCIDAD.}

En cuanto a la caducidad, una sentencia del Tribunal Supremo de 2 de octubre de 1956 (3.236) a la que ya antes hemos aludido, se refiere al caso de que las Ordenanzas municipales dispongan la caducidad de las licencias de obras a los seis meses de su otorgamiento y habiéndose solicitado la rehabilitación expirado dicho plazo, por lo que fue denegada, los derechos particulares no han sido menoscabados, dice, y sólo la desidia y negligencia del actor son las causantes de que no se produzca la prórroga.

CARCELler Fernández (14) admite la caducidad como causa de extinción de la eficacia de licencia debida a la naturaleza temporal de la autorización en que la misma consiste, y se produce por efecto de la no iniciación de los trabajos dentro de cierto tiempo o por la suspensión, dentro de ciertos límites, de la construcción inicial. $\mathrm{Y}$ cita otras sentencias del Tribunal Supremo de 6 de diciembre de 1954, 3 de mayo de 1961 y 12 de enero de 1962 (15).

(14) Ob. cit., págs. 222 y sigs.

(15) Esta última (342) dice que cuando las Ordenanzas municipales establecen como causa de caducidad de una licencia la no iniciación de las obras o actividades que se autorizan dentro del plazo fijado, el Ayuntamiento procede con arreglo a derecho declarando la mencionada caducidad, ya que el otorgamiento de una licencia para algo cuyo comienzo de ejercicio pudiera sin motivo fundado demorarse sine die supondría una dejación definitiva de los derechos y de la actividad de policía de la Administración y una paralización u obstáculo para determinados aspectos de la vida municipal. La Ordenanza municipal correspondiente establece la caducidad de la licencia de obras a los seis meses sin haberse iniciado aquéllas y la declaración más interesante, a nuestro juicio, la hace dicha sentencia al subrayar que «el artículo 15 del Reglamento de Servicios municipales no impide la caducidad de que aqui se trata, basada en que el titular de la autorización no inició las obras para las cuales estaba autorizado en el plazo marcado por aquella norma municipal; pues el mencionado artículo se refiere a la hipótesis de la obra o instalación hecha en las condiciones previstas en la licencia, y declara la vigencia de ésta mientras subsistan o continúen las condiciones en las que la obra o instalación se hicieron, caso distinto al que se enjuicia en este litigio».

Para nosotros esta doctrina peca de oscuridad y ofrece dificultades: se trata de una caducidad-sanción establecida por normas inferiores; el plazo de seis meses parece breve por las razones que diremos, y la teoría de la dejación de funciones de policía por parte de la Administración es difícilmente conciliable con la naturaleza de la licencia que, como dicen otras sentencias, no constituye por sí la obligación de edificar, sino que faculta 
Sin embargo la dificultad surge en cuanto al aspecto fiscal a que este trabajo se concreta. La caducidad como sanción no puede traer consigo otro efecto que el de extinción de la licencia y comportará la necesidad de que antes de acometer la obra o construcción se solicite y obtenga otra. Raramente podrá la Administración denegarla, pues las más de las veces en el breve plazo de seis meses el régimen urbanístico aplicable a la finca o sector seguirá invariable y si la obra para la que nuevamente se solicita licencia es también la misma cuyo proyecto mereció anteriormente autorización, el nuevo expediente o reproducirá inútilmente trámites del anterior o evitará las dilaciones incorporándolos. La caducidad, por tanto, tendrá como efecto nuevo tan sólo el de que por el particular se abone otra vez la tasa ya satisfecha.

La Administración en cambio no tendrá necesidad de desarrollar la actividad a que se refiere el artículo 21 del Reglamento de Servicios.

¿Habrá lugar al devengo de la tasa, si la normativa urbanística aplicable al sector no se ha alterado? La cuestión se ofrece como discutible y dudosa y nosotros nos inclinamos por la solución negativa.

\section{EL ORGANO COMPETENTE PARA EL ACTO DE LIQUIDACION}

El artículo 221 del Reglamento de Haciendas locales dispone que a los efectos del procedimiento económico-administrativo «se entenderá causado el acto administrativo por el acuerdo del Presidente de la Comisión permanente o de la Corporación en pleno que declare o deniegue un derecho o una obligación». $\mathrm{Y}$ consecuentemente con él son reiteradísimas las sentencias del Tribunal Supremo sobre inexistencia de acto y consiguiente nulidad de liquidación de derechos y tasas practicada por funcionario (16).

para realizar la construcción, pudiéndose renunciar a aquella facultad, como dice, por ejemplo, la de 13 de marzo de 1965. En cuanto a la redacción del artículo 15 del Reglamento de Servicios, ha sido muy discutida y tachada de defectuosa.

(16) Citemos las de 24 de abril de 1961 (1.981), 24 de abril de 1962 (1.697) y 22 de marzo de 1966 (1.421). 
La competencia para el acto de liquidación de la tasa por licencia de obras es estudiada por la sentencia de 31 de enero de 1966 (376) la que, recogiendo considerandos de la apelada, concluye ser de competencia de la Comisión municipal permanente la concesión de la licencia de obras, salvo que por Ordenanza haya sido conferida a la Alcaldía (apartado $f$ ) del artículo 122 de la Ley de Régimen local); corresponder a la misma Comisión permanente el desarrollo de la gestión económica y la organización del servicio de recaudación (apartados a) y $g$ ) del mismo precepto legal); mientras que al Alcalde como director de la gestión económica le están reservadas meras funciones ejecutivas, salvo que por delegación, general o especial, le hayan sido conferidas todas o algunas de las de orden decisorio (17).

Es claro que aun cuando uno y otro acto, o uno y otro aspecto de la cuestión incidan dentro de la competencia del mismo órgano al que se refiere la sentencia: la Comisión municipal permanente, el distinto carácter, administrativo y económico-administrativo respectivamente, trae consigo un diferente régimen jurídico de la impugnación, por lo que a los fines de notificación convendrá hacer las distinciones oportunas entre los recursos procedentes para cada materia, pues podría en otro caso inducirse a error.

Pero sobre todo y en comentario a la sentencia antes dicha queríamos referirnos a otra diferencia sustancial que se advierte aquí entre la tasa por licencia de obras y la de apertura de establecimientos. El aludido artículo 122 de la Ley de Régimen local, en su apartado $f$ ) atribuye a la Comisión municipal permanente «la concesión de licencias de obras cuando no corresponda al Alcalde, con arreglo a las Ordenanzas», mientras que el apartado 7.

(17) La sentencia citada en el texto agrega: «... necesario es convenir que tanto el aspecto meramente administrativo de la cuestión-el otorgamiento de la licencia-como el económico-administrativo-liquidación de la tasa correspondiente a la expedición de dicha licencia-es de la competencia exclusiva de la Comisión municipal permanente; y a ello no es obstácuio la norma subsidiaria del apartado i) del artículo 116 de la Ley de Régimen local ni el artículo 221 del Reglamento de Haciendas locales, por cuanto los apartados a) y $g$ ) del artículo 122 de la Ley citada, al atribuir a la Comisión municipal permanente el conocimiento y control de la materia mico-municipal, impide la acción de la norma subsidiaria citada, no se cumple la circunstancia que la condiciona...». 
del aŕículo 121 del Reglamento de Organización atribuye al Alcalde la facultad de «conceder licencias de apertura de establecimientos fabriles, industriales o comerciales y de cualquiera otra indole».

Por su parte, el artículo 22 del Reglamento de Servicios, al someter a licencia la apertura de establecimientos industriales o mercantiles, establece en su número 3 que «cuando con arreglo al proyecto presentado, la edificación de un inmueble se destinara específicamente a establecimiento de características determinadas, no se concederá el permiso de obras sin el otorgamiento de la licencia de apertura si fuere procedente».

Muchas son las reflexiones que podrían hacerse a la vista de la doctrina contenida en la sentencia que antes anotamos. ¿Corresponderá a la Alcaldía el otorgamiento de la licencia de apertura de establecimientos que se citan, y a la Comisión permanente la liquidación de la tasa por dicha licencia? ¿Habrá que entender que el que puede lo más puede lo menos? Es claro que en el supuesto de esta licencia de apertura el Alcalde no actúa por delegación y aquí se nos mostrará entonces «el acuerdo del Presidente», el acto económicó del Alcalde, a que se refiere el artículo 221 del Reglamento de Haciendas, frente a la competencia exclusiva que a la Permanente atribuye en la materia la sentencia indicada.

Por otra parte, el criterio contenido en el número 3 del artículo 22 del Reglamento de Servicios pretende introducir un lógico criterio de equiparación, coordinación o unificación de procedimientos que no armoniza bien con el problema antes apuntado. Tampoco parece existir justificación bastante para esta nueva heterogeneidad entre la tasa por licencia de obras y la de apertura de establecimientos. Algunos retoques legislativos parecen en esta materia aconsejables.

\section{LA INICIATIVA DOMINICAL O PETICION DE PARTE COMO REQUISITO JURIDICO O PRESUPUESTO DE LAA LICENCIA}

El ius aedificandi ha sido un derecho potestativo dentro del haz de facultades integrantes del dominio y al propietario no 
se le discutía la facultad libérrima de ejercerlo o no. El urbanismo moderno ha operado la profunda revolución legislativa de que mientras no tiene la calificación de solar el suelo urbano no puede ser edificado, pero en cuanto reúne aquella calidad no es que el propietario tenga el derecho de edificar, sino la obligación de hacerlo en el plazo que se le fije. Pérez Olea (18) dice que entonces no estamos tanto ante una licencia que levante una prohibición cuanto ante la transmutación de una obligación de no hacer en una obligación de hacer, cambio poco menos que brutal en el régimen de la propiedad que explica la falta de elasticidad mental para comprenderlo desde los viejos moldes privatísticos.

Es discutible, sin embargo, que realmente nos encontremos ante una obligación propiamente dicha. González PÉrez cree que no puede hablarse de una obligación del propietario de edificar, sino de la carga de edificar, y de este parecer es también CARCELLER para quien la Ley del Suelo no llega a configurar la edificación como una obligación, porque no puede exigirse coactivamente; pero sí es en cambio una carga (19).

Albi Cholbi (20) escribe que las autorizaciones requieren, indudablemente, una previa petición de los interesados. "No se concibe una actuación de oficio de la Administración en esta materia, que iría contra la propia esencia de la institución, porque si es la libertad individual lo que la autorización garantiza, resultaría absurda una autorización impuesta». $\mathrm{Y}$ al referirse al problema del interés predominante en el acto autorizado dice: «Para unos-los menos-es interés fundamental el del autorizado. Para la generalidad, es el interés público el que debe prevalecer. Nosotros nos apartamos de ambos criterios, para afirmar que a nuestro juicio la autorización entraña, por esencia, un equilibrio de intereses, ya que si uno de ellos se sintiese menoscabado el acto no se produciria, porque o el particular se eliminaría

(18) Explicaciones de clase de la asignatura «Régimen del suelo», Curso de Información sobre Urbanismo, Instituto de Estudios de Administración Local, 1966-67.

(19) El Registro municipal de solares, Abella, Madrid, 1965, pág CARCEller, El derecho y la obligación de edificar, pág. 239.

(20) Ob. cit., pág. 677. 
espontáneamente, o la Administración denegaría el permiso» (21).

Por eso apuntamos en otra parte de este trabajo que en la orden de ejecución de obras dada de oficio y coactivamente por la autoridad al amparo del artículo 168 de la Ley del Suelo, no hay elemento alguno homogéneo con la licencia, pues falta la voluntad del particular, esencial en la autorización, requisito o presupuesto jurídico para la eficacia de la misma.

La iniciativa dominical o petición de parte que da comienzo al procedimiento y a la actividad que culminará, en su caso, en el otorgamiento de la licencia de obras, late, por supuesto, en la Ley de Régimen local y está expreso en su Reglamento de Servicios.

En otra tasa, la de inspección de motores, la falta de petición o de solicitud ha sido principal fundamento de numerosas sentencias del Tribunal Supremo declarando no haber lugar a la exacción (22).

La anotada doctrina del Tribunal Supremo aparecía así poco sensible a la justificación de la tasa por el servicio provocado a que se refiere tanto el párrafo 1. del artículo 435 de la Ley de Régimen local, como el artículo $10 \mathrm{del} \mathrm{Reglamento} \mathrm{de} \mathrm{Haciendas}$ locales.

Pero recientes sentencias de nuestro más Alto Tribunal dan franca entrada a estas consideraciones. $Y$ así, la ya citada de 3 de febrero de 1967 (351) dice que «... sin servicio utilizable, por indudablemente instalado y positivamente autorizado-sea espontáneamente o a fortiori-no hay tasa fundadamente exigible». $Y$ la de 14 de noviembre del mismo año (4.132) aunque desestima la procedencia de la tasa de inspección industrial, agrega: «lo que no significa que los Ayuntamientos no vengan facultados para su implantación y exacción al incumbirles velar por el interés público del vecindario y su seguridad y comodidad e higiene en su característica labor de policía. Cierto que la exigencia de haberse solicitado la inspección puede ser sustituida como requisito de la legalidad de la exacción por la circunstancia de

(21) Ob. cit., pág. 180 .

(22) Son, entre otras, las de 24 de noviembre de 1958 (3.881); 23 de octubre de 1959 (3.626) y 30 de enero de 1964 (342). 
provocarla especialmente, ya que de otro modo se quedaría el interés público del vecindario supeditado a la voluntad del que instale estos artefactos peligrosos o molestos».

Incluso en otros puntos parece apartarse el Tribunal Supremo de su primitiva posición. Las sentencias al principio expresadas y relativas a la tasa por inspección industrial fundamentaban también su denegación en la falta de beneficio especial y en la duplicidad de servicios con otros de autoridades del Estado. Sin embargo, la sentencia de 1 de marzo de 1967. (810) dice que «la atribución municipal en la intervención de las actividades de sus administrados que la Ley autoriza sometiéndola al pago de tasas, es independiente de la concurrencia de otros permisos o inspecciones que se necesiten para realizar la apertura o puesta en marcha de la central hidroeléctrica, pues como enseña la sentencia del Tribunal Supremo de 19 de octubre de 1964, cada organismo tiene su específica competencia en razón a las finalidades privativas, pero para la actividad a ejercer o ejercida todas las autorizaciones son necesarias, porque todas concurren para que la instalación industrial pueda realizarse legalmente».

Esta doctrina había sido, no obstante, sostenida ya por el Tribunal Supremo en cuanto a la licencia de obras en la citada resolución de 30 de octubre de 1956 (3.556) (23).

Parece, pues, que la policía de la edificación como competencia municipal típica y tradicional, no compartida, tiene mayor aceptación que la de inspección industrial (24).

(23) Decía que «el hecho de que las obras se realicen dentro del recinto cercado, circunstancia normalmente frecuente cuando el particular construye en terrenos propios, no exime en manera alguna la función inspectora reconocida al Ayuntamiento y de la que es expresión la correspondiente licencia; ni tampoco es admisible que la vigilancia de la Jefatura de Minas haga innecesaria la del Ayuntamiento; pues esta exteriorización de sus atribuciones sobre policía urbana en los diferentes aspectos de la misma tiene un carácter y finalidad distintos de los que, con la naturaleza técnica de la actividad de la empresa, corresponden a la Jefatura de Minas».

(24) Ya la sentencia del Tribunal Supremo de 11 de diciembre de 1959 (4.384) dice que el Ayuntamiento no puede, sin infracción del ordenamiento jurídico, mantener inactivas sus facultades en materia de urbanismo, esgrimiendo la mera posibilidad de actuarlas como argumento para dejar prácticamente irresuelta una petición de señalamiento de línea.

Y la de 4 de junio de 1966 (2.936) con invocación de la anterior subraya que denunciada la ejecución de obras sin licencia municipal «debió llevar a la Corporación al ejercicio de las facultades que en materia urbanística el ar- 
También ha cedido el rigor inicial en la exigencia de petición o solicitud de prestación del servicio. La sentencia del Tribunal Supremo de 1 de marzo de 1967 (810), ya citada, dice que «la obligación fiscal no nace si no se ha realizado el servicio, ya sea a petición del particular interesado o porque éste lo haya provocado con actos como el de la puesta en marcha que impongan al Ayuntamiento el deber de su actuación, por ser distinto el hecho de que dimana la necesidad del otorgamiento de la licencia, que es el hecho de la apertura o hecho impositivo diferente al nacimiento de la obligación fiscal de contribuir por la referida tasa, que se produce por la prestación de los servicios».

La de 4 de octubre de 1967 (3.400) aborda un problema interesante: se impugna una tasa liquidada por licencia de obras que no se había solicitado, y dice el Tribunal Supremo «que la sentencia apelada da al precepto aludido una interpretación excesivamente formalista al argumentar que es nula la liquidación por cuanto el entonces recurrente no solicitó expresamente la licencia de apertura y sí sólo la de construcción, y al no expedirse y materializarse en documento la prestación del servicio, ni poderse otorgar tácitamente por el transcurso del plazo al no solicitarse, falta, dice, la base y fundamento de la exacción que es el servicio solicitado y prestado. Esta tesis es errónea por formalista y positivista, porque lo que ha de decidirse es si el acto es o no conforme a derecho y al ordenamiento jurídico para no incurrir en un positivismo superado ya olvidando que lo jurídico no se encierra y circunscribe a las disposiciones escritas, sino que se extiende a los principios y a la normatividad inmanente en la naturaleza de las instituciones, y si es así que se solicita la licencia de obras sabiendo que ésta no se otorgaría sin la de apertura, solicitar en este caso la primera es pedir la segunda, aunque no se materialice en el papel, porque lo importante es que el servicio se preste, ya que el Ayuntamiento conoció del proyecto y de sus condiciones de seguridad, salubridad, etcétera. La falta de pago del servicio supondría una vulneración de

tículo 171 de la Ley del Suelo le asigna y no, como hizo, a mantenerse inactiva, con abdicación implícita de una potestad irrenunciable, de inexcusable ejercicio, que no puede sin infracción del ordenamiento juridico admitirse». 
la Ordenanza y un enriquecimiento injusto de la empresa, aparte vulnerarse el principio de igualdad tributaria...».

\section{LA LEGALIZACION DE OBRAS DEL ARTICULO 171 DE LA LEY DEL SUELO}

No obstante la opinión de quienes consideran que en nuestro Derecho el procedimiento para otorgamiento de la licencia de edificación se inicia siempre a petición de parte, el supuesto b) del número 2 del artículo 171 de la Ley del Suelo, parece ofrecer alguna duda al configurar un procedimiento anormal de otorgamiento de licencia para una construcción iniciada sin ella y que, verificadas las comprobaciones oportunas, aparezca como susceptible de autorización. Estamos ante un procedimiento que se inicia de oficio o a virtud de denuncia y que puede terminar en legalización o autorización.

Salvo que deba entenderse que, dentro del trámite de la suspensión, se habrá de producir expresa petición del particular solicitando aquella autorización, debidamente documentada al efecto $(25)$.

Volvemos entonces a la idea inicial de que la licencia se produce por petición del particular. La materia u objeto de la licencia de obras es aquella cuya descripción aparece en el proyecto técnico que a la petición debe acompañarse. Eúi una contrata el proyecto técnico-que forma parte del pliego de condicionesdescribe la prestación, el objeto del contrato, cierto y preciso. En el procedimiento para licencia de obras el proyecto técnico concreta la pretensión del peticionario. Si las características del proyecto se ajustan a la normativa aplicable y encajan dentro de las posibles soluciones que para una futura edificación el plan permite, la Administración, ponderando debidamente estos factores accede a lo solicitado y otorga la licencia operándose con

(25) Tal parece ser el criterio del Tribunal Supremo en la sentencia de 13 de marzo de 1965 (1.647) cuando dice «... que asiste al recurrente el derecho a continuar la obra hasta la total ejecución del proyecto autorizado o de renunciar a la ejecución del mismo, aun en este supuesto, únicamente podrá mantener lo edificado si es que a tenor de los planes y ordenanzas es legalizable $y$ solicita la legalización...». 
ello la remoción de límites y levantamiento de prohibiciones. Y también el devengo de la tasa.

Late, por tanto, un sentido de congruencia. Si la Administración resuelve de conformidad con lo pedido, se produce el otorgamiento de la licencia solicitada y el devengo de la tasa. Si deniega la petición no se produce el acto de licencia ni la prestación del servicio, ni la consecuencia fiscal anexa. Ahora bien, entre estas situaciones límite hay una gama intermedia de otras: si la Administración impone condiciones, si modifica la obra proyectada por el particular, ¿ha otorgado la licencia o la deniega? La conclusión es trascendental a los fines del devengo de la tasa.

Una sentencia de la Audiencia Territorial de Pamplona de 20 de febrero de 1963 (1.426) dice que «en materia de policía de la edificación solamente da lugar a la correspondiente tasa el servicio consistente en el otorgamiento de licencias para construcciones y obras en terrenos sitos en poblados según el número $7 \mathrm{del}$ expresado artículo 440, por lo cual única y exclusivamente la actividad de licencia para la realización de obras justificará el devengo de la tasa, mas como en el caso debatido la modificación del proyecto por la Corporación municipal no requiere licencia previa, sino una simple aprobación, que es concepto distinto de ja licencia, no puede con base en la aprobación de las reformas introducidas en la obra ya autorizada exigirse el abono de derechos».

No nos aclara la cuestión esta sentencia. Si la Administración municipal manifiesta su voluntad de acceder a la petición particular, de autorizar la edificación solicitada aunque imponiendo condiciones, y si la legalización de edificación sin licencia impone lo propio de manera que la licencia sea para construcción distinta de la solicitada o deseada, se ofrece el problema de si se ha prestado el servicio, se ha producido el hecho imponible y se ha devengado la tasa a que se refiere el número 7 del artículo 440 de la Ley.

En el fondo de la tasa subyace un sentido de contraprestación y aun de equivalencia o proporcionalidad de contraprestaciones. Si al peticionario no le conviene construir inmueble distinto del apetecido y proyectado, creemos que han de surgir gra- 
ves dificultades a la viabilidad de la exacción. Como ya hemos visto, la licencia habilita para llevar a cabo una obra, pero no obliga a ejecutarla. Si la obligación de edificar no resulta de prescripciones urbanísticas en vigor, no podrá ser compelido a edificar y aun así, más que cibligación de edificar existe una carga real. Por otra parte, aquella obligación o carga no se concreta en un tipo uniforme de construcción, siempre hay una opción, una elección, una diversidad de características en la edificación posible y es el particular quien solicitará la licencia y decidirá, dentro de lo permitido, la edificación que se le acomode como objeto de aquella solicitud.

Nosotros creemos que si la licencia es distinta de la solicitada, esto es, si se autoriza edificación diferente de la pedida, hay que concluir que dicha incongruencia supone su denegación, y no habiendo otorgamiento de aquélla no habrá devengo de tasa alguna. $Y$ en el caso de que el acto de licencia imponga modalidades o condiciones mediante las cuales sea posible aquélla y sin las que tendría que ser denegada, para el devengo de la tasa será conveniente acreditar la conformidad del peticionario, bien que ésta realmente se produzca de hechos posteriores del mismo. Es necesaria una confluencia de voluntades del particular y de la Administración, signo ostensible de contraprestación, sin la que el devengo de la tasa parece problemático. Dada la importancia extraordinaria que la licencia de obras ha adquirido creemos conveniente una regulación más explícita de la misma por vía de disposición general.

\section{EL CAMBIO DE PRETENSION}

Si después de otorgada una licencia de obras su titular desea introducir modificaciones en el proyecto técnico que le sirvió de base y hacer una obra en algún modo distinta, ¿estaremos ante el supuesto de nueva pretensión que haya de dar lugar a nueva licencia?

A esta clase de modificación de proyecto parece referirse la sentencia de la Audiencia Territorial de Pamplona a que acaba- 
mos de referimos y que quiere distinguir entre la licencia y la simple aprobación. Parece claro que no se puede sustentar una rigidez $o$ intangibilidad tales que cualquier alteración dé lugar a nueva licencia y nueva exacción. Será menester atender a la entidad de la variación o modificación de que se trate.

Si la modificación es puramente subjetiva estaremos ante un supuesto de transmisión de la licencia que debe ser comunicada por escrito a los fines del artículo 13 del Reglamento de Servicios. Como hemos visto, la licencia de obras se refiere no a las cualidades de un sujeto, sino a las condiciones de una construcción, y se construye en función de ciertas circunstancias objetivas, no personales.

El cambio de pretensión que exija nueva licencia ha de afectar a los elementos sustanciales de la obra, ha de consistir en la modificación esencial del primitivo proyecto, como parece deducirse de la sentencia del Tribunal Supremo de 4 de mayo de 1957 (1.830). Por su parte, la de 24 de mayo de 1963 (3.187) entiende que hay cambio de pretensión cuando se solicita autorización para realizar obras con sujeción a un proyecto en el cual es distinto a aquel que se señalaba en el presentado el emplazemiento de la edificación, «elemento evidentemente esencial cuando lo que se pide es una licencia municipal para realizar obras», por lo que el mencionado cambio de pretensión «priva de finalidad y eficacia a la tramitación promovida por su pretensión anterior...».

\section{EL SUJETO PASIVO DE LA TASA}

El problema del sujeto pasivo de la tasa está ligado al de la legitimación para solicitar la licencia. Puesto que ésta no crea el derecho a edificar, que a ella preexiste, parece legitimado para solicitarla el propietario, titular de ese derecho, y aunque el artículo 12 del Reglamento de Servicios establezca que el acto de licencia no prejuzga el derecho de propiedad, ni la afecte o perjudique.

CARCEller (26) se refiere a la doctrina italiana dentro de la

(26) Ob. cit., pág. 180. 
cual autores como LUCIFREDI consideran que la legitimación para pedir la licencia debe entenderse circunscrita al propietario sin que se pueda extender a los titulares de derechos reales de goce. Otros, como SANDULLI, estiman que la licencia tiene una eficacia real y no personal y hay que considerar que una vez concedida si tiene un sujeto que no está legitimado respecto al inmueble la licencia es válida y operante, pero la obra no podrá realizarse.

GONZÁLEZ PÉREZ (27) cree también en la exclusiva legitimación del propietario, pero dada la salvedad del número 1 del artículo 12 del Reglamento de Servicios entiende innecesario el acreditamiento de aquella titularidad para incoar el procedimiento.

La Ley del Suelo por su parte establece la responsabilidad solidaria del peticionario de la licencia, el propietario, el empresario de las obras y el técnico director de las mismas en cuanto a las infracciones cometidas por ejecución de obras sin licencia o con inobservancia de sus cláusulas legítimas.

Por supuesto, el solicitante de la licencia es frecuentemente persona distinta del propietario, el empresario y el director de la obra. Tanto el mero solicitante ajeno a la propiedad como el empresario están ligados por determinadas relaciones contractuales con el propietario del terreno que va ser edificado. Es posible, y también frecuente, que el dueño del solar sea consocio de otros y que la obra sea promovida por varios o muchos de manera que aun siendo importante el valor del terreno, la persona física o jurídica para quien se construye y que puede ser distinta de la propietaria del terreno, es titular de un interés económico de importancia no menor.

Una interpretación del artículo 9. del Reglamento de Haciendas locales (que beneficia a los contratistas del Estado de la exención de la tasa por licencia que a éste corresponde en determinadas obras) nos lleva a la conclusión de que el empresario o contratista está obligado al pago de la tasa por licencia de obras. Cuando el contratista no lo sea del Estado ni concurran los requisitos del precepto citado, no podrá eludir el pago de la tasa ni siquiera mediante pacto con la propiedad. El número 2

(27) Comentarios a la Ley del Suelo, Boletín Oficial del Estado, Madrid, 1968, pág. 901. 
del artículo 31 de la Ley General Tributaria dice que nunca perderá su condición de contribuyente quien, según la Ley, deba soportar la carga tributaria, aunque realice su traslación a otras personas (28).

El artículo 34 de la Ley General Tributaria dice que la concurrencia de dos o más titulares en el hecho imponible determinará que queden solidariamente obligados frente a la Hacienda pública, salvo que la Ley propia de cada tributo dispusiere lo contrario.

(28) Una sentencia del Tribunal Supremo de 27 de octubre de 1965 (4.572) recoge el siguiente considerando de la apelada:

«Que las partes han polemizado sobre la naturaleza jurídica y la propiedad de las obras, para concretar a quién de ellas pertenece en el contrato de empresa, si al comitente o al arrendatario, pero esta cuestión es de indole civil y no afecta al problema tributario en el cual lo importante es determinar quién es el sujeto pasivo de la tasa de licencia de obras, que en autos está claro en el contrato suscrito entre la Campsa y el contratista, en cuya cláusula 14 se estipula que es el contratista quien se obliga al pago de todas las tasas que con motivo de las obras se hayan de satisfacer a las Entidades locales, lo que indica que, caso de proceder la exacción, se precisaba civilmente a quién correspondía, sin prejuzgar, como se pretende, si se reconocía o no la exacción, si bien como los actos privados de traslación o determinación del impuesto sobre una persona no hacen perder a quien corresponda la condición de contribuyente si no surten efectos ante la Administración, principio hoy claramente reconocido en la Ley General Tributaria de 28 de diciembre de 1963, es necesario concretar quién es el sujeto pasivo de la tasa en cuestión si el comitente o el contratista, en cuyo sentido el Tribunal Económico-administrativo estima que lo son ambos, dada la generalidad de la Ley de Régimen local, que debe delimitarse con más exactitud, ya que quien obtiene la ventaja del servicio público de otorgamiento de la licencia de obras es el contratista, persona que para construir debe previamente conseguir que se autorice la obra, y al respecto lo que la licencia permite es la construcción de la que detraerá la utilidad económica, y que ello es así se deduce de las normas como la Real Orden de 4 de septiembre de 1925 y Reglamento de Haciendas locales de 4 de agosto de 1952, al señalar las exenciones de los contratistas de obras públicas en determinados casos, lo que supone que están sujetos en los demás».

Tanto el comitente como el contratista son sujetos pasivos de la tasa por licencia, según el criterio en autos del Tribunal Económico-administrativo que ni la Sala ni el Tribunal Supremo rechazan. Partiendo de la evidencia de que también ha de serlo el peticionario de licencia, nos conduce todo ello a un supuesto de obligación fiscal solidaria paralelo al que por la infracción urbanística de omisión de licencia establece el artículo 214 de la Ley del Suelo. A su vez, el Decreto de 11 de junio de 1964 sobre construcciones clandestinas dispone en su artículo $2 .^{\circ}$ que la responsabilidad administrativa que fuera procedente podrá ser exigida a los dueños de la construcción, a los del terreno que hayan consentido o tolerado, sin oponerse, la edificación clandestina, y a los moradores de la misma. 
Parece conveniente, sin embargo, subrayar la importancia del propietario del suelo como sujeto pasivo de la tasa. Es él quien ejercita el ius aedificandi y su único titular, por dicha causa, como hemos visto, exclusivamente legitimado para su ejercicio. No pudiendo la Administración quedar vinculada por pactos privados de traslación del impuesto ha de tener siempre en sus manos la facultad de reclamarle. La propiedad de la obra y su naturaleza jurídica ofrece las dificultades a que alude la anterior sentencia. El propietario del suelo, las más de las veces titular registral del dominio, ofrece como contribuyente una garantía de solvencia que no se da en los demás. A nuestro juicio, el propietario del suelo, haya o no solicitado por sí la licencia, es siempre sujeto pasivo de la tasa, pero sería útil una mayor concreción del texto legal o reglamentario en este punto, como se apunta en la transcrita sentencia. La misma distinción entre sujeto pasivo y persona obligada al pago que en la regulación del arbitrio sobre incremento de valor de los terrenos establecen los artículos 517 y 518 de la Ley de Régimen local, sería aquí conveniente y por iguales razones de seguridad para el interés de la Hacienda local.

La materia aparece, pues, un tanto confusa. Cuando la especulación se frustra y los Juzgados despachan ejecuciones sobre el terreno y la obra, ¿qué preferencias puede esgrimir la Administración municipal para llegar a la efectiva percepción de la tasa por licencia no satisfecha?

Si no con frecuencia, el supuesto puede darse. La Administración actuará su propio procedimiento recaudatorio. No parece equiparable la tasa a exacción alguna de devengo regular y periódico por cuya anualidad corriente y por la última vencida quepa la absoluta preferencia a que se refieren los artículos 174 del Reglamento de Haciendas locales y 665 de la Ley. Más genérica $\mathrm{y}$ favorable es la prelación del número 1 del artículo 664 de la misma Ley «en concurrencia con otros acreedores, exceptuando solamente los que lo sean de dominio, prenda o hipoteca» y el artículo 71 de la Ley General Tributaria que establece prelación «para el cobro de créditos tributarios vencidos y no satisfechos».

El Reglamento de Viviendas de Protección Oficial aprobado 
por Decreto 2.114/1968, de 24 de julio, va más lejos, y en su artículo 99 dice que la cédula de calificación definitiva constituirá título suficiente para la toma de razón, por nota marginal en el Registro de la Propiedad, de la declaración de obra nueva. En la misma forma-agrega-se hará constar la afección de la finca para que quede garantizado al Estado, Provincia o Municipio, el pago del importe de las contribuciones, impuestos, arbitrios, derechos, tasas y sus recargos, cuya exención o reducción se hubiere concedido, así como el pago del interés legal de dichas cantidades, en el caso de que se decrete la descalificación de las respectivas viviendas. Es claro que entre aquellas tasas está la de licencia de obras.

En algunas Corporaciones se trata de salvar estas dificultades haciendo uso de la facultad discrecional que les reconoce el número 2 del artículo 437 de la Ley de Régimen local, según el cual, y sin haberse devengado la tasa, pueden los Ayuntamientos exigir depósito previo sujeto a devolución al interesado siempre que por causas no imputables al mismo se dejare de prestar el servicio o de realizar el aprovechamiento. De acuerdo con la Regla 50 de la Instrucción de Contabilidad, este depósito deberá ingresarse en el grupo de «Valores independientes y auxiliares del presupuesto». La sentencia del Tribunal Supremo de 24 de junio de 1968 (3.499) dice que la autorización contenida en el artículo 437 de la Ley de Régimen local «no implica más que un depósito previo, pero sin que se desnaturalice el carácter de contraprestación del servicio que al particular presta el Ayuntamiento».

\section{LA FORMULA DE «PREVIO PAGO»}

La acuñada fórmula de «previo pago de los derechos correspondientes» de que suele hacerse uso abundante y rutinario ha dado paso a cierta creencia de que el pago de la tasa por licencia es condición o presupuesto de la eficacia de la misma.

Hemos visto que la ejecución de la obra y el pago de la tasa no son hechos interdependientes, y que caducada la licencia sin que la obra se haya ejecutado no ha lugar por ello a devolución 
de su importe, según declara la sentencia, ya citada, de 2 de octubre de 1956.

Transcurrido el plazo durante el cual la tasa haya de ser satisfecha, procederá el apremio. La Administración municipal tiene este privilegio y el del depósito previo del artículo 437 de la Ley de Régimen local; y se puede además dirigir contra una pluralidad de sujetos pasivos en reclamación del importe de la tasa. ¿Tiene también el de paralizar las obras por impago de la misma?

Nosotros creemos que no, y que solamente al amparo del artículo 171 de la Ley del Suelo podrá acordarse dicha suspensión. GONZÁlEZ PÉREZ (29) se refiere a las frecuentes infracciones de principio tan elemental de Derecho administrativo como el que prohibe en todo acto incluir elementos accidentales o accesorios que vayan en contra de su contenido esencial. $Y$ dice: «es evidente que, ante estas fórmulas de coacción, ante la perspectiva de ver obstaculizado el ejercicio de la actividad constructora e inactiva la nada despreciable inversión que supone la adquisición de terrenos urbanos, los interesados prefieren pasar por la aceptación de aquellas condiciones con carácter voluntario, a rechazarlas y emplear los recursos admisibles en Derecho».

Hemos visto también que junto al acto de licencia se produce el de liquidación de la tasa, acto económico que tiene diferente régimen de impugnación. Cabe, por tanto, que el particular consienta aquél e impugne éste, y que se dé con ello una discrepancia entre la Administración y el particular que en nada afecta a la licencia, a la obra o construcción, pero sí al importe de la tasa. $Y$ cabe que con afianzamiento obtenga del Tribunal la suspensión del pago de la cuota.

Para nada habrá de afectar esto a la obra en el sentido de imponer una forzosa dilación en la ejecución de la misma, ya que de otro modo se coaccionaría al particular y se dificultaría el libre ejercicio de su derecho a recurrir.

Sobre que la suspensión de la obra, la caducidad o anulación-sanción de la licencia por este motivo, si hubiere precepto legal que le diere amparo, que no lo hay, perjudicaría el interés urbanístico general en que se realice una obra autorizada, daña-

(29) «Las licencias urbanísticas», $R E V L$, núm. 154, págs. 517 y 518. 
ría el derecho del propietario y constructor y en nada beneficiaría a la Hacienda local acreedora que dispone de otros medios idóneos para ejecutar su crédito.

En consecuencia, la tasa por licencia de obras se hará efectiva según lo dispuesto en el artículo 260 del Reglamento de Haciendas, en el plazo voluntario que marquen las Ordenanzas fiscales y, en su defecto, en el de quince días a partir de la fecha en que, previa toma de razón de las liquidaciones respectivas por la Intervención, se notifique a los obligados al pago de la liquidación cuyo ingreso deban verificar. $Y$ pasado este plazo, se incurrirá en apremio.

XII. TRATAMIENTO FISCAL DE LA INFRACCION URBANISTICA: LA INSPECCION DE RENTAS Y EXACCIONES Y LAS OBRAS SIN LICENCIA

La Ley del Suelo reitera en su artículo 214 una doble tipificación de la infracción urbanística que ya ha formulado en el número 1 del 171: obra efectuada sin licencia o con inobservancia de sus cláusulas legítimas. Es, pues, claro que edificar sin licencia constituye aquella infracción.

Ante la construcción sin licencia el ente público debe ejercer su irrenunciable función de policía en los términos descritos en el precepto legal últimamente citado. El 214 define el alcance subjetivo de la responsabilidad, junto con el número 1 del 213. $Y$ el 215 establece una escala de sanciones que para reprimir aquellas infracciones pueden ser impuestas por los Alcaldes, con expresa mención de su carácter gubernativo. Otras disposiciones como la Ley de 24 de diciembre de 1963 y el Decreto de 11 de junio de 1964 completan la materia e integran un sistema, teóricamente perfecto, que hay que enmarcar estrictamente dentro de la legislación de policía.

Sin embargo, los resultandos de sentencias numerosas revelan la extendida práctica de dar como un tratamiento fiscal a la infracción urbanística, constatándola mediante la intervención de los servicios de inspección de rentas y exacciones con levanta- 
miento de acta dentro de los procedimientos y modelos estereotipados para infracciones tributarias e intentando reprimirla con la imposición de sanciones y recargos de aquella naturaleza.

La tendencia a confundir la tasa y el arbitrio o impuesto es antigua y son numerosas las resoluciones judiciales y administrativas que subrayan la distinción y separación.

La Administración económica para poner en marcha sus mecanismos fiscales en el caso en que nos encontramos, necesita de un impulso inicial que es el otorgamiento de la licencia antes de cuyo acto no se ha producido relación tributaria alguna, ni hay contribuyente o sujeto pasivo, ni cuota exigible, ni ocultación fiscal. Al contrario, obvias razones de especulación hacen que sea precisamente obtener la licencia el deseo más ferviente de quien construye con clandestinidad y que, en los más de los casos, aquella construcción se acomete sin licencia a sabiendas de que no podría obtenerse y precisamente por ello.

Mientras las contravenciones recaudatorias se caracterizan por un ánimo o dolo específico de eludir el pago o aminorar la cuantía de la cuota, el infractor de la norma urbanística está generalmente dispuesto a pagar lo que le pidan con tal de poder acreditar que se halla en posesión de la licencia o documento que a ella pueda en algún modo asimilarse. Por ello esta promiscuidad de lo urbanístico y lo fiscal puede ser perturbadora y ocasionar conflictos $(30)$.

La finalidad que persigue la Administración mediante la prestación del servicio de licencias de obras no es recaudatoria, y

(30) Transcribimos de la sentencia del Tribunal Supremo de 24 de octubre de 1955 (3.420) un primer considerando de la apelada que dice: "Que en la demanda originaria del presente recurso ... se interesa la revocación del acuerdo municipal de ..., por el que se denegó licencia para apertura de establecimiento de taller de ajuste mecánico en la calle de ... de esta capital, y que en su lugar se declare el derecho de la recurrente a la misma; y aunque la parte actora fundamenta su demanda en que el Ayuntamiento le había concedido una licencia provisional y cobrados los derechos también provisionales como diligencia inmediata al acta de inspección levantada por lo que no podía después denegarse sin contradecir sus actos propios, sin dudar que el razonamiento es manifiestamente improcedente por cuanto la concesión de la mera licencia provisional como consecuencia del acta de inspección no engendra derecho administrativo alguno, ello no impide a este Tribunal, en el ejercicio de sus facultades revisorias, enjuiciar la legalidad de la denegación por fundamentos distintos a los alegados por el actor...». 
puede decirse sin exageración alguna que el aspecto fiscal de la licencia es secundario, pues le importa muchísimo menos «vender» licencias que velar por el cumplimiento de la ordenación urbanística vigente y denegarlas cuantas veces ésta lo exija, aun a sabiendas de que en tal caso nu se produce devengo alguno (31).

La Circular de 25 de noviembre de 1958 aprobatoria de las Instrucciones para la aprobación de presupuestos de 1959, en su apartado $d$ ) relativo a derechos y tasas por prestación de servicios, observaba que los Ayuntamientos tienden a convertir aquellas exacciones en verdaderos arbitrios municipales y prevenía a los Delegados de Hacienda que tales derechos y tasas «deberán fijarse atendiendo, principalmente, al coste de los mismos, que es el factor predominante de la exacción, considerándose las demás circunstancias, a las que se refiere el artículo 442 de la Ley de Régimen local, como elementos generadores de coeficientes de corrección» (32).

La actividad inspectora de los agentes municipales se habrá de dirigir a comprobar si para determinada construcción ha sido otorgada licencia. Si la comprobación diera resultado negativo procederá cumplir con lo dispuesto en el artículo 171 de la Ley del Suelo, pero cualesquiera actuaciones de carácter tributario, de represión fiscal, serán incongruentes y prematuras, toda vez que el otorgamiento de la licencia no es, ni mucho menos, una consecuencia inexorable del hecho de la construcción.

La actuación inspectora de carácter fiscal se entiende con el contribuyente, y a él se refieren constantemente los artículos 749

(31) Asf dice la sentencia del Tribunal Supremo de 14 de junio de 1967 (3.139) «que la finalidad de las licencias de obras es controlar si el ejercicio de las facultades dominicales se ajusta a las disposiciones que lo regulan y encauzan para acomodarlo al interés público, constituyendo, por tanto, las licencias de construcciones un medio con que el Ayuntamiento cuenta para hacer efectivo su control en materia de urbanismo, obligando a que la obra se ajuste a los planos y proyectos de ordenación urbana aprobados...».

(32) La sentencia del Tribunal Supremo de 10 de noviembre de 1963 (4.677) dice «que siendo según ley, como es, la tasa una contraprestación del servicio que al particular presta el Ayuntamiento, cualquiera que sea la extensión que en la moderna evolución de su concepto clásico pretenda dársele, no puede en absoluto independizarse el importe de la exacción del servicio y es evidente que, aunque no matemática, ha de existir cierta proporcion entre uno $y$ otro...». 
y siguientes de la Ley de Régimen local y. 268 y siguientes de su Reglamento de Haciendas locales. Es el sujeto pasivo a que se refiere el artículo 30 de la Ley General Tributaria. Y en la tasa que nos ocupa la deuda tributaria no nace hasta que no se ha otorgado la licencia.

Palomar Llovet y Rovira Mola (33) dicen que la defraudación presupone la existencia de la relación jurídico-tributaria, o de la deuda impositiva, aunque esté sin liquidar. En tal caso ninguna infracción fiscal habrá podido cometerse en relación con la tasa nonata de una licencia inexistente, con el servicio que no ha llegado a prestarse. Será flagrante una infracción de otro orden y habrá de ser reprimida con arreglo a las disposiciones por que se rige y que hemos visto. Este parece ser el criterio del Tribunal Supremo (34).

Pero la doctrina no aparece suficientemente consolidada. La sentencia del Tribunal Supremo de 27 de octubre del mismo

(33) Las multas municipales en el Derecho español, Ediciones Palestra, Barcelona, 1960, pág. 166.

(34) La sentencia de 24 de marzo de 1961 (1.509): «El hecho de iniciar las obras sin previa obtención del permiso de obras correspondiente reviste ciertamente los caracteres de una falta administrativa sancionable conforme a los artículos 111 y 118, apartado $e$ ), de la Ley de Régimen local...».

Sentencia de 26 de octubre de 1965 (4.615): Se levantó acta a determinada empresa por la inspección de exacciones del Ayuntamiento de ..., por tener instalada sin autorización municipal una serie de máquinas y motores, practicándose la correspondiente liquidación por exacciones municipales que fue recurrida. El cuarto considerando de esta sentencia, de la que es Ponente don Sabino ALVAREZ-GENDín Y Blanco, dice: «Que respecto del apartado $7 .^{\circ}$, «licencias para construccion», si el Ayuntamiento reconoce que la construcción del complejo industrial y su instalación objeto de expediente de tributación se hizo sin licencia, lo procedente era imponer sanciones con arreglo a las facultades que confiere a los Alcaldes la Ley de Régimen local si la obra se levantó antes del Reglamento de Industrias molestas de 30 de noviembre de 1961 y en coordinacion con el entonces vigente Reglamento de Industrias incómodas de 17 de noviembre de 1925, y si fue posterior a la vigencia de aquél, de acuerdo con el artículo 38 de tal Reglamento en relación con el 29 y siguientes en la redacción dada por el Decreto de 5 de noviembre de 1964, sin perjuicio de que a la empresa interesada se le obligue a subsanar el defecto de tramitación de la licencia del establecimiento y presentar la oportuna instancia de rehabilitacion, y si procediesen las inspecciones municipales y se otorgase la licencia por el Ayuntamiento o la Comisión provincial de Servicios Técnicos, se cobrarían entonces las tasas concernientes a los servicios prestados y a la licencia otorgada, sin obstáculo para la conferida por la Jefatura provincial de Industria. Que por la misma razón no era procedente cobrar las tasas de inspección hasta que se efectuasen éstas...». 
año 1965 (4.572), a la que ya antes nos hemos referido, implícitamente admite la posibilidad defraudatoria en un caso de acta levantada por la inspección de rentas y exacciones a una edificación sin licencia que descarta aquella calificación de defraudación por no estar probada la conducta elusiva del pago de la cuota y haberse facilitado los documentos precisos. Es de interés la muy reciente sentencia del mismo Tribunal Supremo de 24 de junio de 1968 (3.499) que versa sobre los siguientes hechos: practicada liquidación por el concepto de tasa por licencia de obras en razón de haber suscrito el empleado de una empresa una «llamada» acta de invitación (considerando primero de la apelada) fue interpuesta reclamación que el Tribunal Económico-administrativo provincial estimó y ordenó la devolución de la cantidad pagada a la empresa, sin perjuicio de que una vez que se acredite la prestación del servicio municipal pueda el Ayuntamiento exigir los derechos o tasas que le correspondan con arreglo a la Ley. Interpuesto recurso contencioso-administrativo ante la Audiencia Territorial fue desestimado aunque sin confirmar la reserva de actuación formulada. Apelada la sentencia se confirma.

Pero el problema de si puede mantenerse la liquidación practicada cuando aún no había sido concedida la licencia de obras, aunque enunciado entre los que plantea el recurso no es abordado después, ya que, declarada la inaplicabilidad de la tasa por tratarse de un supuesto de obra fuera de poblado, no es necesario examinar las restantes cuestiones, «si bien todas coadyuvan, con más o menos vigor, a la desestimación de la demanda», dice el último considerando de la apelada (35).

En especial, respecto al punto que más nos interesa y es el

(35) No obstante, dice la citada sentencia «que en el caso de autos el acta de invitación carece de valor, pues el verdadero acto administrativo definidor de derechos y obligaciones es la liquidación subsiguiente, no el acta; y que cuando se habla de la conformidad de un contribuyente en un acta de invitación se sobreentiende que ello corresponde al plano de los hechos y no a las consecuencias que de los mismos pretende sacar la Administración; la aceptación del contribuyente se liga al pronunciamiento previo sobre la cuota fiscal determinada y concreta, pues si en la Ley de Régimen local se admite una renuncia anticipada, no es en materia de recargos, sino de multas, y dentro de los expedientes especialmente instruidos para resolver las mismas, con lo que la existencia previa de una liquidación se da también en estos supuestos (art. 756)». 
del valor de la liquidación practicada antes de otorgarse la licencia, dice: «Los hipotéticos efectos vinculantes de ese consentimiento son aún más inexplicables en el caso de autos, si se pien-. sa que aquí el referido Ayuntamiento ha mostrado una mayor diligencia en la percepción de la tasa que en la prestación del servicio...». $Y$ en el segundo considerando del Tribunal Supremo, «que si bien el artículo 437 de la mencionada Ley autoriza a los Ayuntamientos para poder exigir el previo pago de los derechos o tasas correspondientes, esta autorización no implica más que un depósito previo, pero sin que se desnaturalice el carácter de contraprestación del servicio que al particular presta el Ayuntamiento, por lo que no puede llegar a independizarse en absoluto el importe de la tasa y el servicio hasta el extremo llegado por la Corporación de... girando la liquidación en agosto de 1964 y no realizando el servicio hasta el 8 de enero del siguiente año...». 